\title{
Postwar University Library Buildings in West Germany
}

A report on twenty recently constructed West German university libraries based on visits by the author. Included are discussions of the relations of the central library with other libraries on the university campus; location of the central library; division of services in it; provision for readers, collections, technical services, and administrative offices; and architectural details.

A

A

FTER 1914 AND UNTIL THE 1950s and 1960 s, there was little construction of academic libraries in West Germany. World War I, inflation, and the Hitler period intervened. In the course of World War II a number of libraries were partially or totally demolished. In the postwar period, however, with the number of students seeking admission to universities increased, the period was one of planning and construction. This study of buildings constructed after World War II is based on visits to twenty university libraries in the Federal Republic of Germany. The visits occurred in the spring and summer of 1973 during the course of a sabbatical leave of the author.

Before the visits, letters and requests for information were sent to selected directors of university libraries in West Germany. Literature was consulted, and suggestions were obtained from Dr. Ralph Ellsworth. ${ }^{1-4}$ In the course of the trip valuable counsel was received from Dr. Franz Kröller, director of libraries at the University of Graz. Throughout

Harold D. Jones is associate professor, Library Department, Brooklyn College, Brooklyn, New York. the visits, host librarians were most cordial and helpful.

\section{INSTITUTIONS VISITED}

Institutions of higher education in the Federal Republic of Germany, with the exception of a few theological seminaries, were publicly maintained under the direction of the Ministry of Education of the several states. Other exceptions are the Free University of Berlin (part of whose building costs were provided by the Ford Foundation) and the Technical University of Berlin, financed by the city. Of the twenty institutions visited, one, Aachen, is a technical college (Technische Hochschule), four are technical universities (Munich, Hanover, Braunschweig, Berlin), and the remaining fifteen are universities.

Five of the universities were established in this century: Constance (1966), whose library is most like those on American campuses; Mannheim (1907); Saarbrücken (1948); Frankfurt am Main (1914); and the Free University of Berlin (1948).

The University of Cologne had its beginnings in 1388, and the universities of Munich, Tübingen, and Mainz trace their origins to the fifteenth century. 
Marburg was established in the sixteenth century, and the Christian-Albrecht University of Kiel and the Justus Liebig University of Giessen were founded in the seventeenth. The University of Bonn and the technical universities of Berlin and of Braunschweig were established in the eighteenth century. Four of the institutions visited were founded in the nineteenth century: the Technische Hochschule at Aachen, the Technical University of Munich, the University of Karlsruhe, and the University of Stuttgart. (Onethird of the cost of the library at Stuttgart was provided by the Max Kade Foundation, Inc., of New York.)

At three universities the libraries occupy new quarters in older buildings restored after World War II: the Ludwig-Maximilian University of Munich, the University of Mannheim, and the Technical University of Berlin.

At the Eberhard-Karls University of Tübingen a small 1912 Jugendstil library was first enlarged with a massive storage stack (Magazin). Both are joined to a new modern extension which houses most reader services, technical services, and administrative offices. Libraries at the Free University of Berlin and at Constance are connected with other buildings as part of a unified plan.

Looking at the new structures in turn, one notes that modern postwar architectural styles prevail. But, recalling the swift changes in library design that took place in the United States during and after World War II and subsequently in Great Britain, it becomes clear that in the Federal Republic of Germany an older tradition still holds sway. The visitor will not find divided marble stairways, but there are high-ceilinged rooms with mezzanines. One does not find monumentality, except at Cologne, but most books are housed in separate stacks which are closed to readers.

The notable exception is the library at the University of Constance, com- pleted, except for a planned extension, in 1973. Its stacks stand one upon the other, but are accessible to readers. Every other reading room floor is splitlevel with respect to the stack levels above and below and are reached by a short stair. Elevators stop at all levels.

Some of the soon-to-be-completed libraries on new campuses will depart in some respects from the traditional system. But even so, to understand the new library buildings, the American librarian must recognize the pervasiveness of a tradition and set of practices that only recently have begun to change.

\section{Organization OF THE LIBRARIES}

Faculty members and students at a university in the Federal Republic of Germany are served by a central university library, numerous small independent institute and seminar libraries, and larger departmental or subject area (Fachbereich) libraries. At Frankfurt am Main and at Cologne the main library is a city library as well, though for scholarly, not popular, reading.

There may be more than 100 institutes on a given campus, each directed by a chair-holding full professor (Ordinarius). Institutes may each have a library of a few hundred or a few thousand volumes. Some of the subject department libraries-in law, economics, or Germanistik, for example-may have 50,000 . Most of the institute libraries are supervised by an assistant to the professor, who, according to one German librarian, "likes to be within slipper distance of his books." Books in the institute libraries are on open shelves, are classified according to a locally devised system, and do not circulate, except in some libraries on weekends. There are stories, as there are in the United States, of readers from one institute not being welcome in the library of another.

There is some evidence of attempts to develop coordination among the many libraries on a campus, but none 


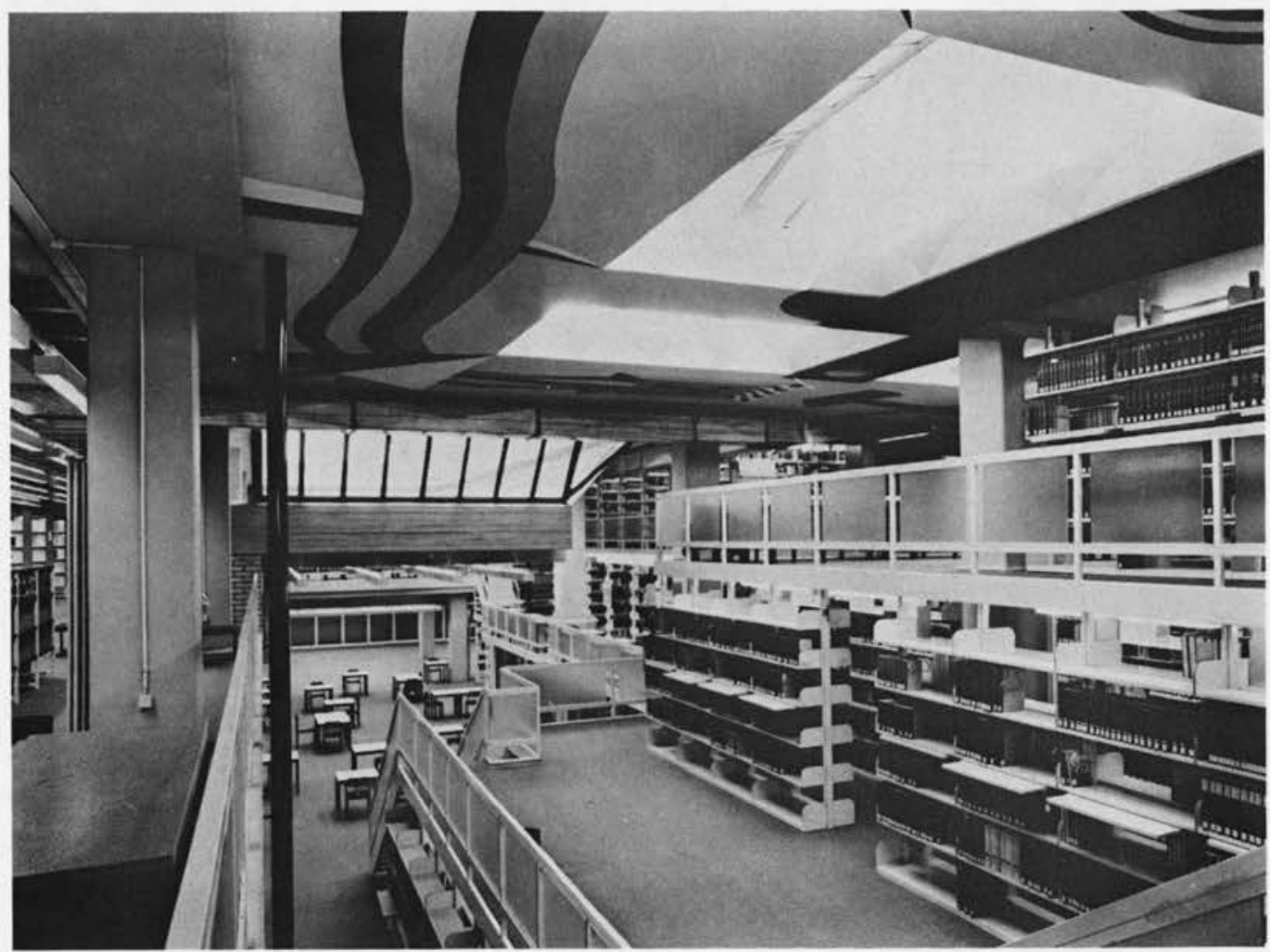

Library, University of Constance. Reading and Stack Area.

of centralized direction or budgeting. Library and other budgets are planned at the state level, not by the local university administration. In the State of Hesse a new law provides that the director of the university library is in charge of all libraries. In Schleswig-Holstein the law says that the libraries on a given campus constitute a single unit. But as stated by one library director, in the face of long-standing tradition one has to proceed very slowly. ${ }^{5}$ On some campuses the faculty library committee attempts to achieve coordination through union catalogs or the consolidation of several small libraries into larger ones.

At Marburg one of the subject specialists of the main library provides liaison service with fifteen seminar and institute libraries. At Kiel there is a union catalog in the main library listing the holdings of eighteen of the independent on-campus libraries in the humani- ties. At Constance, although there is only one library, a separate science library is to be built. At Regensburg, however, there will be a library system, with a central library and ten coordinated departmental libraries. At the Free University of Berlin some coordination is to be achieved by listing in a union catalog the books, serials, and periodicals of two faculty libraries (medicine and veterinary medicine), the library of law, 136 institute libraries, and twentyfour clinic libraries.

\section{Features of New Libraries}

The sites of the newly constructed libraries vary although most campuses are in cities. The library of the University of Munich is bordered on one side by a main thoroughfare, and about 300 yards away is the Bavarian State Library, available to university students 


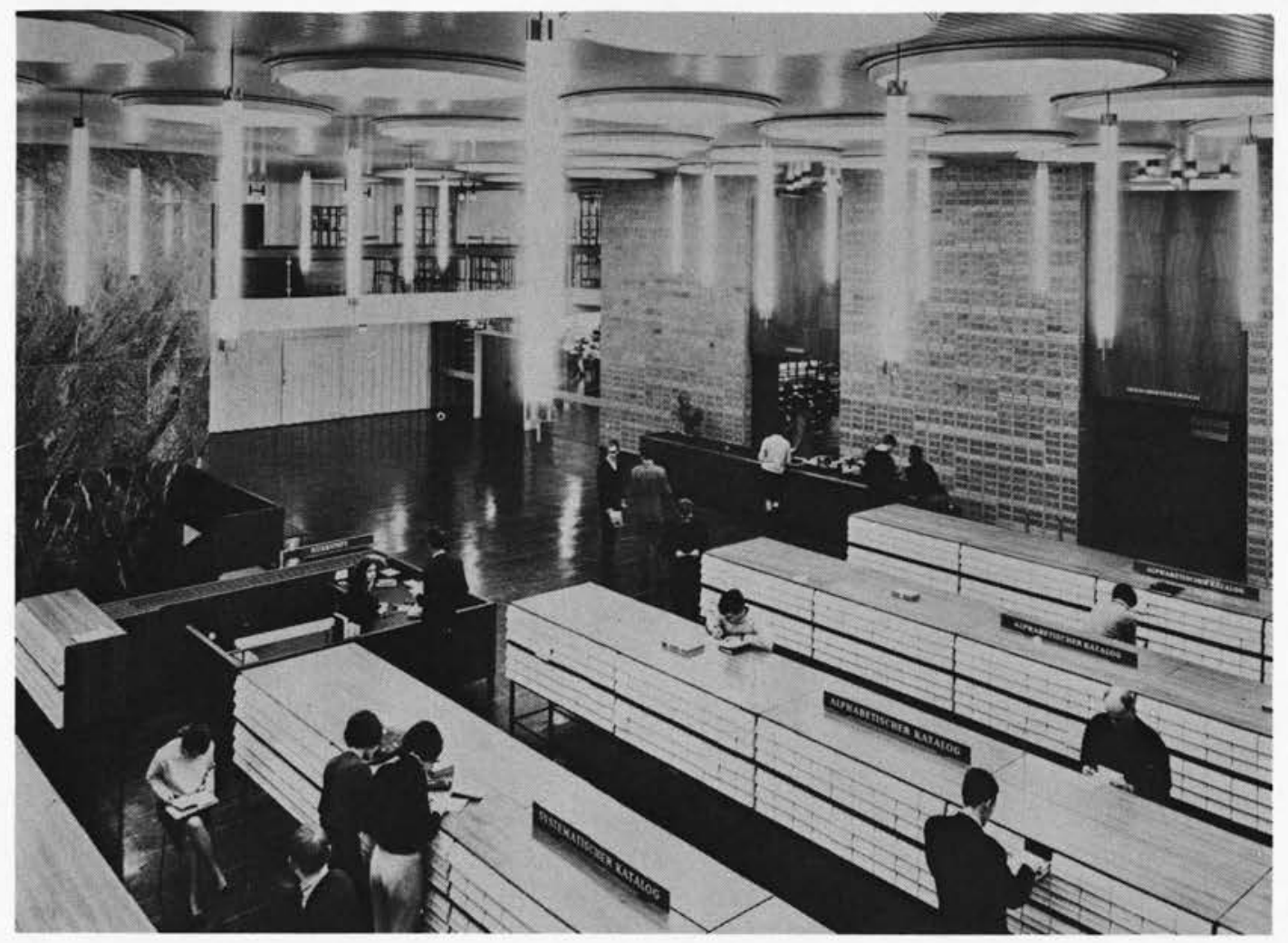

Library, University of Kiel. Public Catalog and Information Desk.

and faculty members. The Technical University of Munich, also on a busy street, expects to move to a new campus outside the city within twelve years. The library, with 300,000 volumes, now occupies the second floor and basement of a classroom and laboratory building.

The University of Constance occupies a generous tract about a twenty-minute drive from the city center. The buildings, including the library, are in a cluster, each accessible through a central plaza. Tübingen is in the university quarter of the old city. A local ordinance forbids the erection of a high rise structure; a stream runs behind the old and new library buildings, and an adjacent plot has been reserved for a faculty office building. With 1.6 million volumes, the library is now filled to capacity.

The plan for the library at Kiel was the result of an invited competition.
The library was built in 1966 and stands at a busy intersection near other university buildings. It has shelf space for 1.2 million volumes; and its holdings now total 1 million volumes. It has three stories above ground but was not permitted to build farther upward, because the city wanted the university administration building to stand taller than all others. There is a single basement level, as funds did not permit the construction of a two-level basement.

The University of Stuttgart and its handsome library are a fifteen-minute walk from the main railway station. The library has its own generous grassy plot. A delivery entrance is reached from a major traffic artery. Much the same can be said of the library of the Technical University of Hanover. The Johannes Gutenberg University of Mainz moved after World War II from the old city. It is bordered on one side 


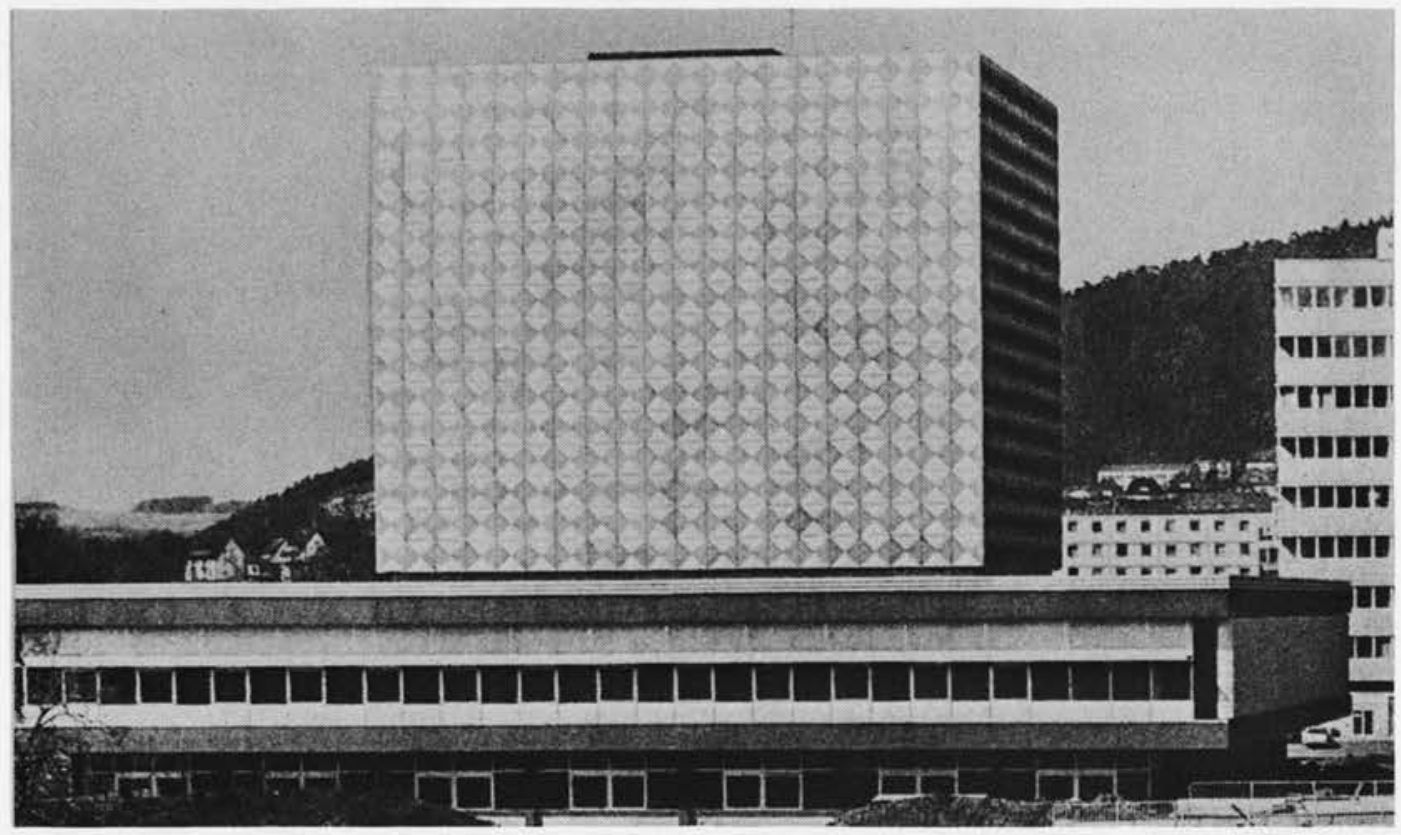

Library, University of Marburg. Nine-Story Stack Tower atop Two-Story Platform.

by a major highway, but it has its own campus with room for expansion. An extension of the library building is planned.

Many buildings of the Phillips University of Marburg/Lahn occupy nonadjacent sites in the old city. The library, the student union, and several classroom buildings for the humanities occupy a pleasingly landscaped campus within sight of thickly forested hills. A science-medical complex, with its own library building, will be located outside the city.

Most of the sites visited were level, but at Aachen, Karlsruhe, and Braunschweig there is sufficient slope to provide a basement delivery entrance. The library of the Rheinische Friedrich-Wilhelms University of Bonn has a grass plot in front, a parking lot on one side, and a site which slopes downward to a retaining wall, below which are a highway and the Rhine. In general, libraries are near classroom buildings; and extensive student dormitories are not found on German university campuses.

\section{Division OF SERvices}

Architecturally, the university libraries emphasize a traditional separation of space for readers, for administrative and technical services, and for book storage. This is clearly evident from the building masses at Saarbrücken, Mainz, Giessen, and the Free University of Berlin, where there are architecturally separate book stack towers. At Giessen the tripartite arrangement is emphasized by the fact that the thirteen-story rectangular book tower is faced with dark blue ceramic tile, while the square, one-story-with-mezzanine reading room is faced with offwhite tile bearing an abstract decoration.

At Marburg a square-shaped twostory platform containing the public and technical service areas and the administrative offices supports a nine-story metal-clad stack tower.

Stuttgart, Hanover, and Kiel are three-story buildings with basements, the first two employing a great deal of glass. 


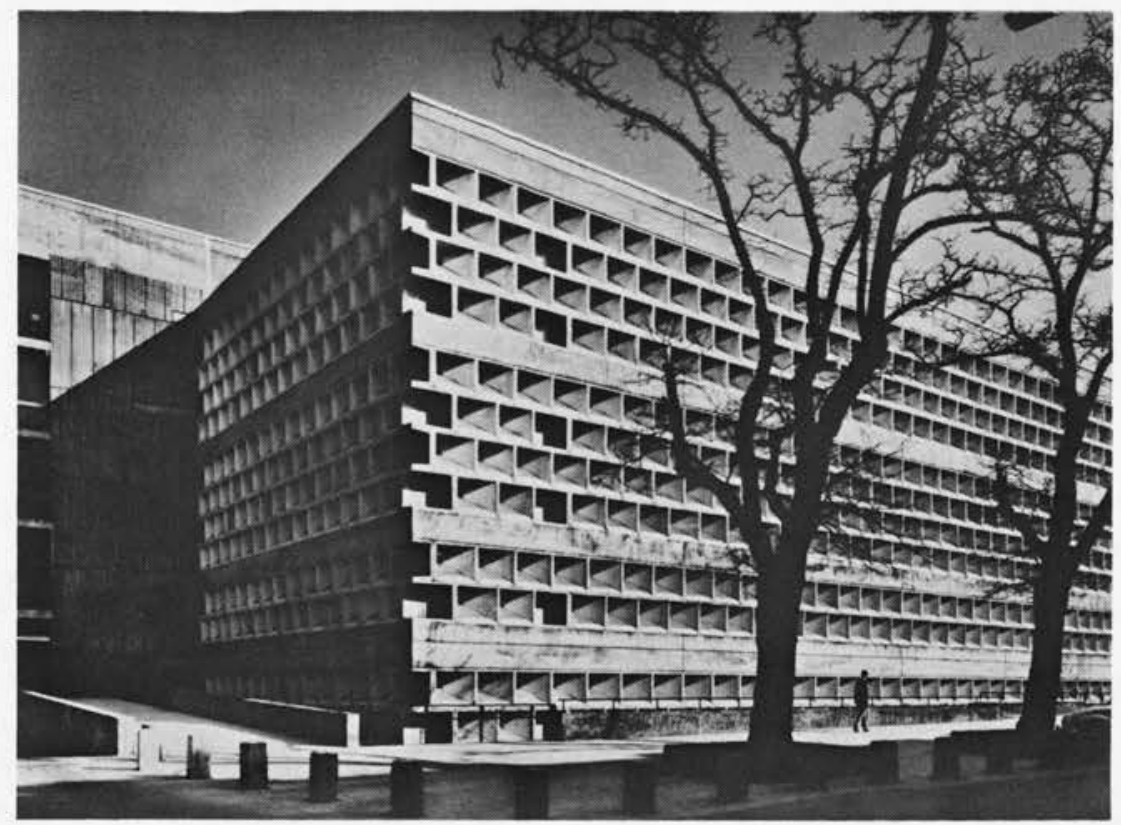

Library, University of Cologne. The Stack Wing.

The library at Karlsruhe is a thirteenstory narrow rectangular slab building of reenforced concrete. A dry moat brings daylight to the front basement of the building. Although pleasing to the eye, both inside and out, it is an architect's-not a librarian's-building. Because of a central core containing elevator shafts, stairway, and service desks, each public floor is divided into two parts; and they are connected by corridors.

At Aachen the library is in two units, a brick bookstack structure adjoining and connected with a rectangular sixstory building of reenforced concrete and glass, for readers and technical and administrative services.

Cologne, the largest of the German university library buildings $(252,000$ square feet), has two wings with stack area in one and administration and technical services in the other. The latter unit also houses the library school of Rhineland-Westphalia. Three reading rooms, each about thirty-four feet high, and space for other public services stand on columns one floor above grade level.
Clear glass panes of various sizes and shapes and glass brick are combined to provide surface interest. A small pool occupies part of the lawn in front and extends under the reading rooms.

The City and University Library at Frankfurt am Main consists of two major units: a building (three stories and basement) for public services and administration joined at the ground floor through a wide corridor to a four-story reading and stack building. A three-level basement stack is located under the latter unit.

Sharing a spacious plaza with an administration and auditorium building, the library of the Technical University of Braunschweig consists of four stories and a two-level basement. The first floor is larger than the upper floors and, unlike most of the libraries visited, provides space for the technical service offices. Amber-tinted glass is used on the first and second floor exteriors. On the fourth floor the concrete wall is interrupted on two sides by fifteen projecting faculty studies. An arcade protects two sides of the first floor from direct 


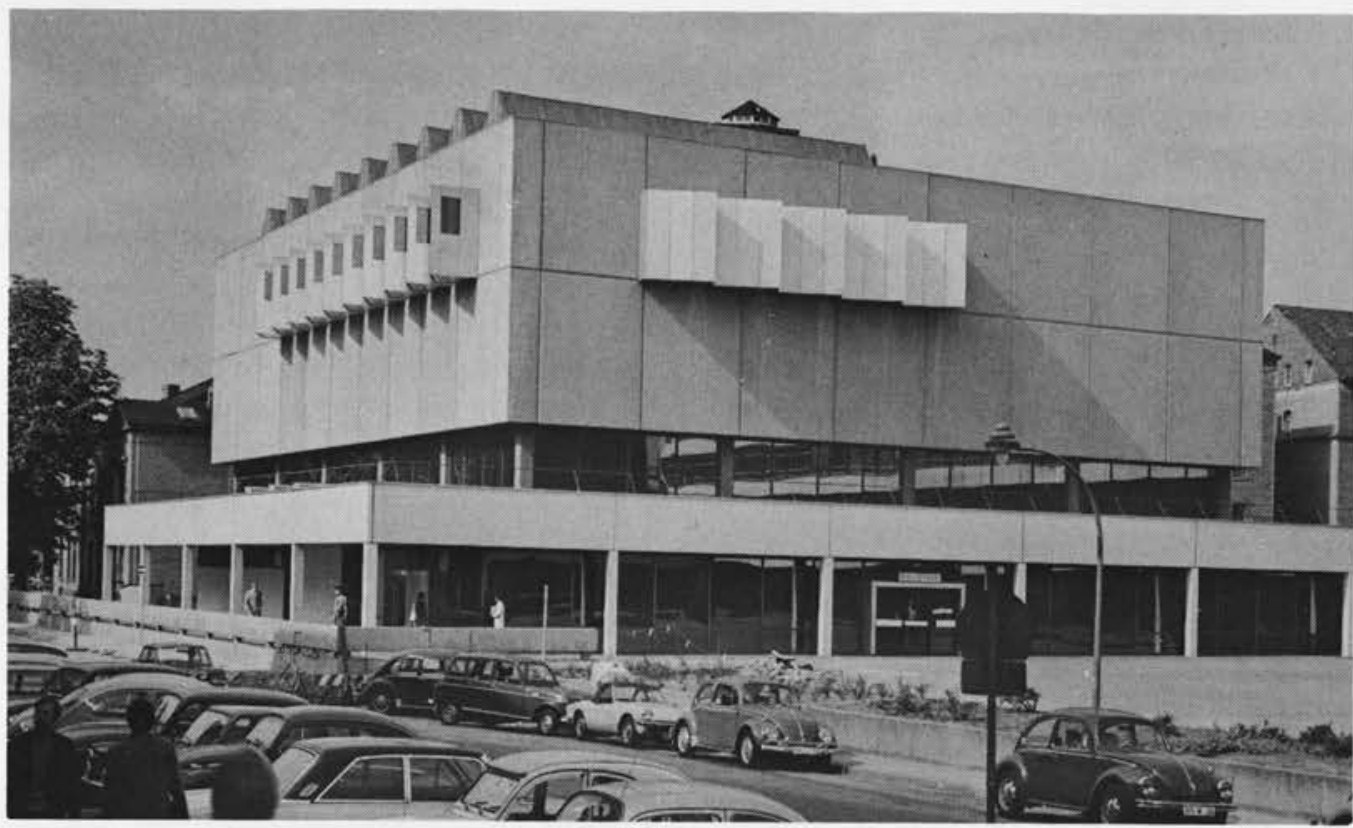

Library, Technical University of Braunschweig.

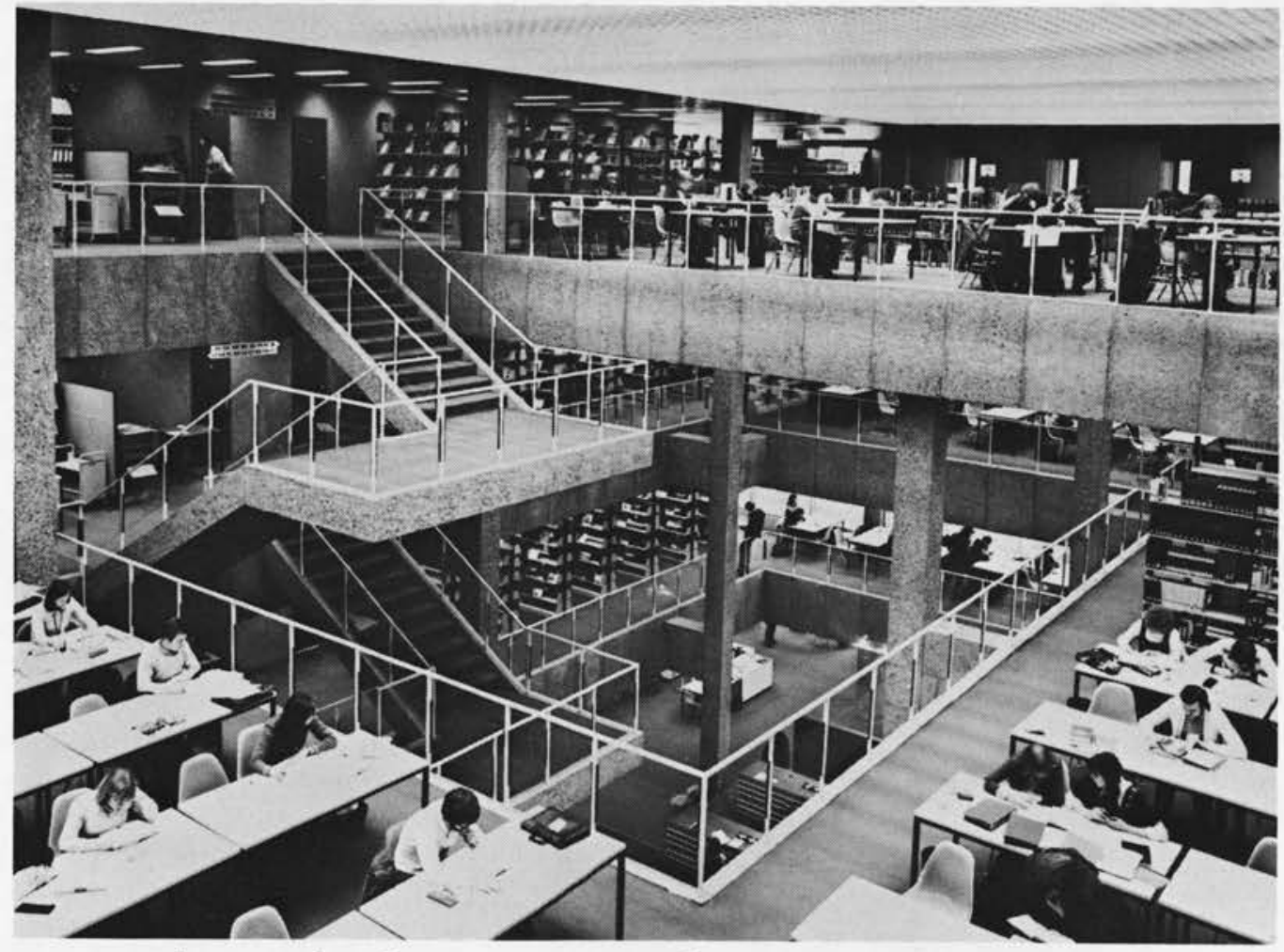

Library, Technical University of Braunschweig. Reading Area and Stairwell. 
sunlight. In appearance this library is very much like some built in the United States. Space for books, periodicals, and readers is provided on the three upper floors. There is an eye-catching but space-wasting stairwell.

\section{Space for Readers and Collections}

After a few visits to university libraries in the Federal Republic of Germany, one concludes that because the tradition and philosophy are different, the buildings are different from those in the United States.

Within the entrance to a typical university library in West Germany, one finds a manned or self-service check room. Here readers are required to leave their overcoats and hats and briefcases. Most often one finds the current newspaper reading area nearby. Usually furnished with molded plastic and tubular metal chairs, a low table or two with ashtrays, and sometimes a beverage vending machine, this area is the nearest approach to informality seen in German university libraries.

One next arrives at the public catalog area, sometimes on the ground floor, sometimes on the floor above. It is generally roomier than the American counterparts. Catalog cases are on high metal bases. Vertically, the cases hold only six rows of trays. Cases are usually clearly marked with large signs to indicate whether author or subject. Several of the libraries, Frankfurt am Main, for example, have union catalogs of the scholarly collections of the state. The technical universities receive cards from various documentation and indexing services. Nearby there is usually an information desk. A reference department providing the in-depth service to which we are accustomed is not to be found.

Since circulating books are kept within a closed and separate stack, the circulation desk is not adjacent to the exit but is placed in a functional relation- ship to the stacks and to the mechanical book transportation system.

Books are paged, as they were in American university libraries before World War II, in response to the submission of call slips by readers. Paging service is not available for all hours that the library is open. At Cologne, for example, the circulation desk opens at ten o'clock in the morning, closes at noon, and reopens at three o'clock in the afternoon. Service is uninterrupted at some of the libraries but is not available for all hours the library is open. At Tübingen, the author was informed that paging is available two hours a day only. Several of the libraries offer a highspeed paging service for readers whose need is especially urgent. A handful of the libraries have computerized circulation systems. The library that remains open on Saturday afternoon or on Sunday is the exception.

Books in the stacks are not classified, but arranged numerus currens in the order in which they are acquired; and neither students nor faculty members are admitted to the stack area. The author observed the following sequence of books on one shelf in the stack of the Free University of Berlin: A monograph on war research followed by a biography of Seyss-Inquart; next was Beyond Berkeley; then Proto Indo European Trees; followed by Letters of Kant.

Stacks have vertical and horizontal conveyors, the latter very often suspended from the ceiling. All are connected with the circulation desk by pneumatic tubes and electric signals. Extensive "Compactus" or similar shelving arrangements are found in basements.

Several libraries show variations: Braunschweig and Frankfurt am Main have a number of reading rooms, and a higher percentage of their books and bound periodicals are on open shelves. Stuttgart has an open appearance as well. The main collection at Constance 
is on open shelves and is arranged by subject according to a locally devised system.

There is usually one main reading room, although Cologne, Frankfurt am Main, Hanover, and Braunschweig, for example, have several subject reading rooms. Reading rooms usually have high ceilings and contain mezzanines. There usually is a skylight in the ceiling; and as there are no additional book or reading areas above, as in many American university libraries, construction is lighter; and the area is not interrupted by columns. One wall, as at Mainz or Saarbrücken, is likely to be largely window. At Kiel there are plastic domes instead of clerestory skylights. During the day neither ceiling lights nor desk lamps, found in some reading rooms, are likely to be turned on. This is true in technical processing offices as well; illumination levels are lower than in American libraries. Exceptions are Kiel, Braunschweig, Stuttgart, and Constance. Many of the libraries also have interior light courts to provide readers and staff offices with natural light and a view of greenery.

Reference books, using a local classification system, are found in the reading rooms on wall shelves, on free standing stack sections, or on shelves located under mezzanines. Usually at the entrance there is a floor plan and an explanation of the classification system and a catalog of holdings. German university libraries are uniformly good in the quality of the plastic location signs, on the top edges of shelves, indicating subject matter. Handwritten, makeshift signs were commendably absent.

Current issues of periodicals, usually about 1,500 of the most used, are found in separate open shelf reading rooms. Unbound recent issues are requested at a desk. The exception is Braunschweig, where the current issues are on open shelves with the bound volumes.

The atmosphere of reading rooms is more studious and formal than in American libraries. In all but three, readers sit facing one way. Tables for two are lined up side by side in many rows. Near the exit, or at the end of the room, is a supervisor's desk. Some reading rooms and technical service areas are carpeted. The reading room tables in at least half the libraries are of white-topped plastic with black metal legs. Seats are most often of molded plastic on metal tubular legs. A few libraries have chairs with textured plastic backs and seats. Readers are notably respectful of the rights of others. There is little conversation, no candy wrappers, or plastic cups. In a few libraries there are separate conversation areas, but the general atmosphere is one of quiet.

German university libraries do not provide lounge furniture, individual carrels, or study desks. The periodical reading room at Hanover did contain a three-piece upholstered settee facing two inviting chairs with a low table between them. The author's hosts explained that the officials of the ministry of education, which provides funds, believe that austerity rather than comfort is more productive of true scholarship.

Only Braunschweig provides individual study facilities for faculty members. Many of the libraries have small, separate reading rooms for faculty members and, sometimes, for doctoral candidates.

Frankfurt am Main has thirty-one enclosed lockable booths in the large open stack area on its first floor. It also provides several enclosed listening rooms equipped with turntables and speakers. Some of the libraries have typing rooms.

Audiovisual services, as known in some American university libraries, are not found. Some services of this nature, the author learned, are located in teacher training institutes. Several libraries house a recorded speech collection (Sprachlabor) not managed by the li- 
brary. None were open when the author sought to visit them.

The average number of seats for readers in the central libraries is about 400. Cologne, with 18,000 students and 1.5 million volumes, has 750 seats. Constance with 2,000 students has 290 seats. The greatest number of seats is at Frankfurt am Main (student body of more than 15,000 ) with 800 in its fourstory stack and reading room building.

All libraries have self-service copying machines. Nowhere were drinking fountains visible. Several of the larger libraries have snack bars, but like the staff rooms they are strictly utilitarian.

For a five-year period, until 1971, the Volkswagen Foundation provided funds with which the university libraries of West Germany purchased multiple copies of the most used assigned textbooks. As a result, in the public service areas, often near the main reading room, one finds a textbook lending collection, totalling about 15,000 volumes. This is the nearest approach to the American reserve book room service, although these areas are open fewer hours than the library itself. Loan periods vary from campus to campus; on some campuses books are lent for several months. For the last three years library budgets have provided the funds for the continuance of this popular service. One of the hosts pointed out that students would rather save up for a new car than spend their money on textbooks, a phenomenon not limited to West Germany.

The older libraries have great rarities in the form of manuscripts or early printed books, and there may be a separate reading room for them. The papyri room at Giessen is an example. But there are no elegantly furnished rare book display areas. At the University of Munich the author was shown a manuscript book of music often consulted by visiting scholars. It was shelved in a very plain attic stack area with oth- er treasures. At the University of Cologne a rare history of the city, with hand-colored woodcuts, was on an ordinary shelf at the far end of a stack level.

\section{Offices for Technical Services AND ADMINISTRATION}

Technical service departments most often occupy interconnecting rooms rather than one or two large areas. Usually they are in a part of the building at some distance from the public cata$\log$ and the bibliographic section, and not on the main floor. Furniture, desks, and cabinets are most often of wood rather than metal. Catalogers' desks, separated by partitions of shelving, are seen infrequently. As in the United States, staff members improve the decor by means of colorful prints and plants.

Active gift and exchange departments are found, partly because of the widespread exchange of dissertations. There are duplicating offices and, often elaborate, photographic departments and book restoration and binding services. Periodicals usually go to commercial binderies, but dissertations and other publications are reproduced and bound by the central library.

A noteworthy feature in the administrative wing is the series of offices, usually reached from an asceptic and isolated corridor, occupied by the Fachreferenten. These librarians are the subject reviewers or bibliographers, usually holders of a university doctorate and of the highest grade library school diploma. They select 90 percent or more of the books acquired by the main library. ${ }^{6}$ Their offices are likely to be somewhat more commodious than those of subject bibliographers in American university libraries. The author never saw one without a window. These staff members also hold administrative responsibility, for example, chief of reader services, or head of acquisitions. It is the function of the Fachreferenten to check in- 
coming books and cards set aside for them on special shelves in the catalog departments. They are also available to readers for consultation.

\section{Architectural Details}

The libraries visited show considerable variation but not the same evidence of a striving to make a great creative statement that one finds on many American campuses. Most were designed by official architects. As stated earlier, Kiel's plans were the result of an invited competition. The author learned that architects do not always consult librarians, and that by and large they are inclined to conservatism.

Here and there one sees some interesting details. Outside, and on the wall just inside the entrance at Tübingen was a large leaflike sculpture of hammered metal. On the spacious lawn in front of the Stuttgart library was an abstract sculpture of the "bent girder" school. Near the entrance to the stack and reader area at Frankfurt am Main was a wondrously tall metal sculpture, Prometheus, by Zadkine. At Kiel the generous use of wood, of patterned ceramic tile interior walls, and good lighting were pleasing. And there, too, one finds towering near the information desk a figure in wood entitled All too Impractical Throne (Allzu unpraktische Thron), by Jan Koblasa of Prague. On the lawn in front of the Bonn library are several biomorphic pieces of marble. Near the entrance of the library at Aachen stands a group of tall metal figures closely knit like intensely argumentative students.

At Karlsruhe at the end of a reading room is a round cast-stone plaque and a colorful cartoon. At Constance outside a wing of the library, and just as high, stands a pyramid of colorful plastic spools. The reading room wall just below a skylight is decorated with streaks of color by an artist with psychedelic inclinations. Saarbrücken shares a pleasant reflecting pool with other new buildings. Most libraries offer modest exhibits of new books or of book jackets. At Cologne there was a display of products from publishers in the city. None of the libraries offered a helpyourself new book shelf. Giessen featured a professionally prepared display on Justus Liebig, the nineteenth-century professor of chemistry for whom the university was named and among the first to establish a chemical teaching laboratory.

\section{Conclusions}

Because the underlying traditions and philosophy are different, the library buildings are different from those in the United States. German libraries emphasize custodianship of resources; they offer less to their readers in the way of access, comforts, and amenities. They are less inviting and colorful. Their books are compactly shelved, and they provide seats for a relatively small percentage of their student bodies, so they are generally less imposing then their American counterparts. They do command the respect of their readers, and there is little of the adolescent clubhouse atmosphere, due perhaps, in part, to the fact that students do not enter the university in Germany until about the age of nineteen. Almost all German university libraries, through assignments by the national research commission (Forschungsgemeinschaft), have responsibilities for developing special collections: Scandinavian literature at Kiel, Slavonica at Munich, medicine at Cologne, for example. Hanover serves as the national library of technology. As a result, considerable space is assigned to interlibrary loan and exchange services.

The stacks of several recently built libraries will soon be filled to capacity and will require extensions. Their directors are aware of other shortcomings, especially the wastefulness inherent in the separate nonsystem of uncoordinat- 
ed institute libraries. New libraries, especially those of recently established universities, will reflect the desire for change and liberalization, but academic libraries in the Federal Republic of Germany will change only gradually. If librarians have their way, flexible, service-oriented buildings, standing at the center of coordinated on-campus library systems, may presently emerge.

\section{REFERENCES}

1. Ralph E. Ellsworth, Academic Library Buildings (Boulder, Colo.: Associated University Pr., 1973).

2. Franz Kröller, "Moderner Bibliotheksbau: West- und Mitteleuropa," p.69-77; and
"Ausstellung, 'Moderne Bibliotheksbauten,'” p. $185 \mathrm{ff}$, in Österreichisches Institut für Bibliotheksforschung, Symposium moderner Bibliotheksbau (Wien: Österreichische Nationalbibliothek, 1971), Biblos-Schriften, Bd. 56.

3. Gerhard Liebers, Bibliotheksneubauten in der Bundesrepublik Deutschland (Zeitschrift für Bibliothekswesen und Bibliographie, Sonderheft 9) (Frankfurt am Main: Klostermann, 1968).

4. Gisela Von Busse and Horst Ernestus, Libraries in the Federal Republic of Germany (Chicago: American Library Assn., 1972).

5. For an illuminating, detailed explanation of these and other aspects of the German library system see J. Periam Danton, Book Selection and Collections: A Comparison of German and American University Libraries (New York: Columbia Univ. Pr., 1963), p.35, 43-57.

6. Ibid., p. $34-38$. 